\title{
ANNUAL REPORT \\ OF THE DIRECTOR OF THE DRAWING SCHOOL OF THE FRANK- I.IN INSTITUTE, FOR THE SESSIONS I888-I889.
}

The number of pupils attending the Drawing School has been less this year than last, but as other similar schools have had the same experience, it is evidently due to outside causes and does not indicate any loss of prestige. On the contrary, the system of instruction has been greatly improved, and the efficiency correspondingly increased. This is particularly the case with the Junior and Intermediate Classes in Mechanical Drawing, where all problems not directly useful have been eliminated, and the course so modelled as to be logical, concentrated, concise, and at the same time more comprehensive than ever before. Excellent opportunity is given the pupils to become thoroughly grounded in the principles, and any failure on the part of any of them to profit by it, is due either to natural incapacity or to want of appreciation of or lack of attention to, the theoretical studies which constitute a large portion of the work. If those desirous of learning Mechanical Drawing would only commence at the beginning and go understandingly through the entire course, they would become thoroughly interested in the subject and would, at.the end, be in a position to make themselves immediately useful in a draughting office or industrial establishment, and would have mastered things which, as apprentices in such establishments, they would never get an opportunity to learn.

This is equally true of those desiring to take up Architectural Drawing. It is the ability to handle crooked, complicated and difficult problenıs that makes any individual architect, draughtsman or mechanic more valuable than his fellows, and although a natural gift of genius may occasionally supply the place of education and training to some extent, yet such gifts are rare, and even when they do occur, the education has to be obtained afterwards by overwork.

The Free Hand Classes have been favored this year with an unusual amount of natural talent and have consequently been very successful. Considering the total number of hours actually spent at the work, the quantity and quality of the result attained make a gratifying showing.

Much credit is due to the ability and earnestness of the instructors: Messrs. Clement Remington, Willis H. Groat, John F. Rowland and George W. Irons.

The following pupils are entitled to Honorable mention :

In the Senior Mechanical Class.

William H. Schalliol, Howard W. White, Thomas W: Lawrence, A. S. Berquist, Lucien E. Picolet, John Morris Bush.

Whole No. Vol. CXXVII. -(ThIRd Series, Vol. xcvii.) 32 


\section{In the Intermediate Classes.}

John S. Rooke, Charles W. Godfrey, Gustav Friedler,

George C. Tilton, Clifford M. Talley, Robert G. Hienerwald, Alexander H. Watt, Donald Frazer, W. E. Wilkinson.

In the Junior Mechanical Classes.

Frank S. Thompson, John G. Johnson, J. Hüster,

John Simpson, Henry J. Upp, James L. Garnett, W. A. Leavitt, Jr.

In the Architectural Class.
George W. Haldeman.
Charles B. Jarden,
Paul A. Davis, Henry Kerr.

In the Free Hand Class.

Robert F. Schleicher, Charles Nacke, Arthur B. Davenport, Oscar Wenderoth, Kate F. Dinan.

In the Oil-Painting Class.

Charles A. Koch, Mrs. L. Nace, George Lethy.

The following pupils are awarded scholarships from the B. H. Bartol Fund, entitling them to tickets for the next term, beginning September 23, I889:

Intermediate Mechanical Class.

John S. Rooke,

Donald Frazer.

Junior Mechanical Class.

Frank S. Thompson, J. Hüster.

Architectural Class.

Paul A. Davis.

Free Hand Class.

Robert F. Schleicher.

The following pupils having attended a full course of four terms, with satisfactory results, are awarded certificates to that effect :
Louis Eichhorn,
James Exley,
George E. Drum,
William H. Schalliol,
Charles W. Leng,
William Grieser,
Howard W. White,
George Bardsley,
George W. Haldeman,
Lucien E. Picolet,
Henry H. Alcock,
Daniel McLaughlin,
Thomas W. Lawrence,
Emil Lukert, William Bartholomew,
Morris T. Patterson,
George Fred. Becker,
Charles Doellber,
William L. Bushnell,
William Halpin, Kenneth J. Easby, Howard M. Craig, John Morris Bush, George S. Neff, John Kenney,
William C. Gray, George H. Robinson,
William C. Brockmeyer, Leburton P. Gardner, Frederick De Ginther, William H. Lippert, Howard L. Dunlop. 
It is to be regretted that the class-rooms are not sufficient to accommodate the entire school on two evenings in the week, as was the original practice. Such an arrangement would increase the energy and enthusiasm and remove the tiresome effect of continuous night work from the instructors. The school sessions could then be fixed on different evenings from the lectures, and thus avoid the annoyance to the lecturer and audience, caused by the noise on the stairway, made by a few ill-bred and unruly pupils during the exit of the classes. I shall endeavor to plan a rearrangement of the rooms to accomplish this.

William H. Thorne, Director.

\section{Franklin Institute.}

[Proceedings of the Stated Meeting, held Wednesday, May 15, 1889.]

\section{Hall of the Franklin Institute, Philadelphia, May 15, 1889 .}

Joseph M. Wilson, President, in the Chair.

Present, 128 members and sixteen visitors.

Additions to membership since last report, 39 .

Mr. S. Lloyd WIEgand was elected as a trustee of the Elliot Cresson Fund, to fill the vacancy caused by the death of JOHN WIEGAND.

Mr. James S. McCoy, of New York, gave a description of the Pneumatic Tool of the American Pneumatic Tool Company and exhibited the tool in operation surfacing and engraving stone, engraving upon wood, executing repoussé work, etc. Specimens of the products were exhibited.

The subject was referred for investigation to the Committee on Science and the Arts.

Mr. Fred. E. Ives made some remarks on the subject of portable optical lanterns, and exhibited vertical lantern, megascope, microscope, polariscope and spectrum projection attachments of novel construction, adapted to his portable folding lantern.

Mr. IvEs' improvements were referred to the same committee for investigation and report.

Mr. S. Lloyd WiEgand presented an abstract of the report of the Committee on Science and the Arts on "James Atkinson's Gas Engine," illustrating the subject by the use of a number of lantern slides.

The Secretary's report embraced some comments on the Paris Exhibition and the exhibition of a number of views of some of the most notable of the various buildings and structures.

Adjourned.

WM. H, WAнL, Secretary. 